\title{
Optimasi Dosis Pupuk Kandang Ayam dan NPK pada Budidaya Kubis Bunga (Brassica oleracea var. Botrytis L.)
}

Irpan Gunawan ${ }^{1}$, Atak Tauhid ${ }^{2}$ dan Isna Tustiyani ${ }^{2 *}$

${ }^{1}$ Alumni Program Studi Agroteknologi, Fakultas Pertanian, Universitas Garut, Garut, Indonesia; ${ }^{2}$ Program Studi Agroteknologi, Fakultas Pertanian, Universitas Garut, Garut, Indonesia

Diterima: 25 Maret 2021; Disetujui: 29 April 2021

\begin{abstract}
Abstrak
Kubis bunga merupakan salah satu jenis sayuran yang sering dikonsumsi. Permintaan akan kubis bunga semakin meningkat sehingga perlu peningkatan produksi melalui pemupukan. Penelitian ini bertujuan untuk mengetahui pengaruh perlakuan dosis pupuk kandang ayam dan pupuk NPK terhadap pertumbuhan dan hasil kubis bunga. Penelitian dilaksanakan di Desa Sukasenang, Kecamatan Banyuresmi, Kabupaten Garut dari bulan Juli sampai Agustus 2019. Penelitian menggunakan Rancangan Acak Kelompok (RAK) dua faktor masing-masing faktor 3 taraf dengan 2 kali ulangan. Faktor pertama adalah dosis pupuk kandang yang terdiri dari tiga taraf yaitu 0,10 dan 20 ton pupuk kandang; faktor yang kedua dosis pupuk NPK yang terdiri dari 0, 100, $200 \mathrm{~kg}$ NPK $\mathrm{ha}^{-1}$. Data dianalisis dengan uji F, jika berbeda nyata akan diuji lanjut dengan uji DMRT. Peubah yang diamati antara lain tinggi tanaman, jumlah daun, luas daun, berat dan diameter krop. Hasil penelitian menunjukkan bahwa tidak terjadi interaksi antara dosis pupuk kandang ayam dan NPK. Perlakuan dosis 20 ton ha ${ }^{-1}$ pupuk kandang ayam mempengaruhi tinggi tanaman, jumlah daun dan luas daun kubis bunga. Perlakuan dosis $200 \mathrm{~kg} \mathrm{ha}^{-1}$ pupuk NPK mempengaruhi tinggi tanaman, jumlah daun, berat dan diameter krop kubis bunga.
\end{abstract}

Kata kunci: berat krop; diameter krop; dosis; krop; luas daun

\section{Optimation of Various Rates of Chicken Manure and NPK Fertilizer on Cauliflower farming (Brassica oleracea L.)}

\begin{abstract}
Cauliflower is one of the vegetables for consumers. The demand for cauliflower was rising so it must be scaled up with fertilizer. The purpose of this study was to study the effect of chicken manure and NPK fertilizer on the growth and yield of cauliflower. The study was conducted in Sukasenang Village, Banyuresmi Sub-district, Garut Regency from July to August 2019. The study used a Randomized Block Design (RBD) in two factors each of the 3 rates with 2 replications. The first

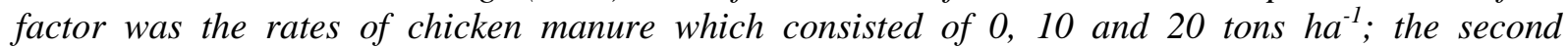
factor was NPK fertilizer which consists of 0,100 and $200 \mathrm{~kg} \mathrm{ha}^{-1}$. The parameter of this research was plant height, number of leaves, leaf area, weight and diameter crud. The results showed that there was no interaction between the chicken manure and NPK fertilizer. The treatment of 20 tons $\mathrm{ha}^{-1}$ chicken manure affected the variable plant height, the number of leaves and leaf area.
\end{abstract}

\footnotetext{
*Corresponding author: isnatustiyani@gmail.com

Cite this as: Gunawan, I., Tauhid, A., \& Tustiyani, I. (2021). Optimasi Dosis Pupuk Kandang Ayam dan NPK pada Budidaya Kubis Bunga (Brassica oleracea var. Botrytis L.). AgriHealth: Journal of Agri-food, Nutrition and Public Health, 2(1), 32-38. doi: http://dx.doi.org/10.20961/agrihealth.v2i1.49828
} 
The rates of $200 \mathrm{~kg} \mathrm{ha}^{-1}$ NPK fertilizer had affected plant height, number of leaves, weight and diameter crud.

Keywords: cauliflower; crud; crud diameter; crud weight; rates

\section{PENDAHULUAN}

Kubis bunga (Brassica oleracea var. Botrytis L.) atau kembang kol merupakan salah satu komoditas sayuran yang dikonsumsi massa bunganya (curd). Kubis bunga tergolong dalam famili kubis-kubisan (Cruciferae). Kandungan zat gizi kubis bunga lengkap dan cukup tinggi nilainya. Kandungan gizi kubis bunga antara lain : kalori $31 \mathrm{kal}$, protein 2,4 g, lemak 0,4 g, karbohidrat 6,1 g, serat 0,6 g, abu 0,8 g, kalsium $34,0 \mathrm{mg}$, fosfor $50,0 \mathrm{mg}$, zat besi $1,0 \mathrm{mg}$, natrium $8,0 \mathrm{mg}$, kalium $14,0 \mathrm{mg}$, niacin $0,7 \mathrm{mg}$, vitamin A 95,0 SI, vitamin B1 0,1 mg, vitamin B2 0,1 mg, vitamin C $90 \mathrm{mg}$ dan air 90,3 g (Rukmana, 1994).

Berdasarkan data Badan Pusat Statistik (BPS, 2015), produksi kubis bunga di Indonesia pada tahun 2011 sebesar 113,491 ton, tahun 2012 sebesar 135,837 ton, dan tahun 2013 sebesar 151,288 ton, sedangkan pada tahun 2014 mengalami penurunan menjadi 136,514 ton. Pertumbuhan tanaman dipengaruhi oleh faktor genetik dan lingkungan (Tustiyani et al., 2014). Faktor lingkungan yang mendukung antara lain unsur hara di dalam tanah. Upaya untuk menaikkan produksi kubis bunga dapat melalui berbagai cara, salah satunya yaitu melalui pemupukan. Pupuk mengandung unsur hara yang dibutuhkan oleh tanaman baik unsur hara makro maupun mikro. Unsur hara utama yang dibutuhkan tanaman dalam jumlah cukup besar adalah nitrogen, fosfor dan kalium (Prawoto dan Hartatik, 2018).

Pupuk majemuk (NPK) merupakan salah satu pupuk anorganik yang dapat digunakan sangat efisien dalam meningkatkan ketersediaan unsur hara makro utama ( $\mathrm{N}, \mathrm{P}$ dan $\mathrm{K})$, menggantikan pupuk tunggal seperti Urea, SP-36 dan $\mathrm{KCl}$ yang pengaruhnya hanya satu fungsi yang kurang seimbang terhadap pertumbuhan tanaman. Pupuk organik merupakan pupuk yang ramah lingkungan (Shaila et al., 2019). Salah satu jenis pupuk organik adalah pupuk kandang. Pupuk kandang memiliki kandungan hara yang dapat mendukung kesuburan tanah dan pertumbuhan mikroorganisme, serta mampu memperbaiki struktur tanah (Mayadewi, 2007). Penggunaan pupuk kandang yang dikomposkan juga dapat meningkatkan kesuburan tanah, pertumbuhan serta hasil padi sawah (Sugiyanta et al., 2021).

Menurut Murbandono (2000), penggunaan bahan organik seperti pupuk kandang ayam mempunyai peran penting bagi perbaikan mutu dan sifat tanah antara lain memperbesar daya ikat tanah yang berpasir (memperbaiki tekstur tanah berpasir), memperbaiki tekstur tanah berlempung sehingga tanah yang semula berat akan menjadi ringan, memperbesar kemampuan tanah menampung air sehingga tanah dapat menyediakan air lebih banyak bagi tanaman, memperbaiki drainase dan tata udara tanah (terutama tanah berat) sehingga kandungan air mencukupi dan suhu tanah lebih stabil, meningkatkan pengaruh positif dari pupuk buatan, mempertinggi daya ikat tanah sehingga tanah menjadi lebih tahan, tidak mudah larut oleh air pengairan.

Menurut Bahri (2006), sumber pupuk dapat mempengaruhi pertumbuhan kubis bunga antara lain tinggi tanaman, lebar daun, diameter daun, diameter bunga dan produksi kubis bunga. Media tanam yang mengandung bahan organik lebih banyak akan meningkatkan diameter kubis bunga (Husnihuda et al., 2017) dan hasil tanaman sawi (Saepuloh et al., 2020). Pupuk NPK dapat meningkatkan diameter kubis bunga (Arpanto dan Soenyoto, 2018), tinggi tanaman (Armidayani et al., 2020), bobot krop (Prawoto dan Hartatik, 2018; Amalia et al., 2019). Kombinasi pupuk organik dan pupuk NPK dapat meningkatkan pertumbuhan dan hasil kubis bunga (Diana et al., 2020; Putri et al., 2021). Namun belum terdapat kajian mengenai pengaruh kombinasi aplikasi dosis pupuk NPK dan pupuk kandang ayam pada budidaya kubis bunga. Berdasarkan latar belakang tersebut maka dilakukan penelitian aplikasi dosis pupuk NPK dan pupuk kandang ayam pada kubis bunga untuk mengetahui pengaruhnya terhadap pertumbuhan kubis bunga.

\section{BAHAN DAN METODE}

Percobaan dilaksanakan di Desa Sukasenang, Kecamatan Banyuresmi, Kabupaten Garut, 
Provinsi Jawa Barat. Jenis tanah Inceptisol dengan $\mathrm{pH}$ 5,91 berada pada ketinggian 500-750 $\mathrm{m} \mathrm{dpl}$ (meter di atas permukaan laut). Percobaan dilaksanakan pada bulan Juni sampai Agustus 2019. Bahan yang digunakan antara lain benih kubis bunga varietas Bima-45, pupuk kandang ayam yang berasal dari kotoran ayam broiler yang sudah dikomposkan, pupuk NPK Phonska, insektisida berbahan aktif fipronil (Regent 50 SC). Alat yang digunakan antara lain cangkul, kored, handsprayer, pisau atau golok, tali rafia, bambu, meteran, penggaris, jangka sorong, timbangan, kertas label dan perlengkapan alat tulis.

Metode yang digunakan dalam penelitian ini adalah dengan menggunakan Rancangan Acak Kelompok (RAK) pola faktorial $3 \times 3$ dengan 3 kali ulangan. Faktor pertama adalah Pupuk Kandang Ayam (K) terdiri dari 3 taraf yaitu 0, 10 dan 20 ton ha ${ }^{-1}$. Faktor kedua yaitu pupuk NPK yang terdiri dari 0,100 dan $200 \mathrm{~kg} \mathrm{ha}^{-1}$. Pupuk kandang diaplikasikan sebelum tanam, sedangkan pupuk NPK diaplikasikan saat tanaman berumur 5 MST (Minggu Setelah Tanam).

Analisis ragam digunakan untuk menguji pengaruh pemberian pupuk kandang dan pupuk
NPK terhadap pertumbuhan dan hasil kubis bunga, dilanjutkan dengan uji Jarak Berganda Duncan (Duncan Multiple Range Test) jika terjadi beda nyata antara perlakuan pada $\alpha=0,05$.

\section{HASIL DAN PEMBAHASAN}

\section{Pertumbuhan tanaman}

Pemupukan merupakan salah satu faktor yang mempengaruhi pertumbuhan tanaman karena pupuk akan membantu menyediakan unsur hara bagi tanaman. Pupuk yang digunakan dalam percobaan ini adalah pupuk kandang ayam dan pupuk NPK yang diaplikasikan pada tanaman kubis bunga. Hasil penelitian menunjukkan tidak terdapat interaksi antara berbagai dosis pupuk kandang ayam dan dosis pupuk NPK terhadap parameter tinggi tanaman kubis bunga (Tabel 1). Hal ini diduga kombinasi dosis pupuk kandang ayam dan dosis NPK majemuk memberikan pengaruh sendiri-sendiri sehingga respons tanaman sama pada setiap peubah yang diamati. Hal ini juga terlihat pada penelitian Diana et al. (2020) yang menyatakan bahwa tidak terjadi interaksi antara perlakuan pupuk kandang dengan NPK pada tanaman kubis bunga.

Tabel 1. Hasil analisis tinggi tanaman

\begin{tabular}{|c|c|c|c|c|}
\hline \multirow{2}{*}{ Perlakuan } & \multicolumn{4}{|c|}{ Rata-rata tinggi tanaman $(\mathrm{cm}) \mathrm{ke}-$} \\
\hline & 7 HST & $14 \mathrm{HST}$ & $21 \mathrm{HST}$ & 28 HST \\
\hline \multicolumn{5}{|c|}{ Dosis pupuk kandang ayam } \\
\hline 0 ton ha $^{-1}$ & $13,06 \mathrm{~b}$ & 20,79 a & $30,31 \mathrm{ab}$ & $40,23 \mathrm{a}$ \\
\hline 10 ton $\mathrm{ha}^{-1}$ & $12,28 \mathrm{a}$ & $20,23 \mathrm{a}$ & 29,43 a & $38,71 \mathrm{a}$ \\
\hline 20 ton $\mathrm{ha}^{-1}$ & $12,45 \mathrm{ab}$ & $20,87 \mathrm{a}$ & $30,93 \mathrm{~b}$ & $40,08 \mathrm{a}$ \\
\hline \multicolumn{5}{|l|}{ Dosis pupuk NPK } \\
\hline $0 \mathrm{~kg} \mathrm{ha}^{-1}$ & $12,01 \mathrm{a}$ & $19,56 \mathrm{a}$ & $29,04 \mathrm{a}$ & $37,97 \mathrm{a}$ \\
\hline $100 \mathrm{~kg} \mathrm{ha}^{-1}$ & $12,63 a b$ & $20,96 \mathrm{~b}$ & $30,34 \mathrm{~b}$ & $39,63 a b$ \\
\hline $200 \mathrm{~kg} \mathrm{ha}^{-1}$ & $13,15 \mathrm{~b}$ & $21,37 \mathrm{~b}$ & $31,29 \mathrm{~b}$ & $41,41 \mathrm{~b}$ \\
\hline
\end{tabular}

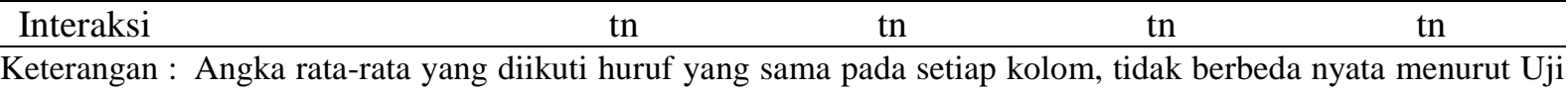
Jarak Berganda Duncan pada taraf 5\%; HST $=$ Hari Setelah Tanam; tn = tidak nyata

Perlakuan 20 ton pupuk kandang ha ${ }^{-1}$ dan $200 \mathrm{~kg}$ NPK ha-1 merupakan perlakuan terbaik terhadap parameter tinggi tanaman karena menghasilkan nilai tertinggi dan meningkat dari periode pengamatan awal sampai akhir. Hasil ini diduga karena unsur hara dalam perlakuan tersebut lebih tinggi dibandingkan perlakuan yang lain sehingga dapat membantu meningkatkan proses fotosintesis secara maksimal. Hal ini sesuai dengan pernyataan Rinsema (1989) bahwa unsur hara yang optimal sangat berperan dalam merangsang perkembangan seluruh bagian tanaman sehingga tanaman akan lebih besar. Hal ini sejalan dengan penelitian Arpanto dan Soenyoto (2018), Armidayani et al. (2020), Putri et al. (2021) bahwa pupuk NPK dapat meningkatkan tinggi tanaman kubis bunga.

Pertumbuhan tinggi tanaman kubis bunga mengikuti pola pertumbuhan dimana pada saat fase vegetatif mengalami peningkatan, setelah 
memasuki fase generatif sudah tidak terjadi pertambahan tinggi tanaman lagi karena translokasi fotosintat sebagian besar digunakan untuk perkembangan organ-organ generatif. Pada umur 28 HST terlihat bahwa perlakuan pupuk kandang tidak memberikan pengaruh pada peubah tinggi tanaman. Hal ini diduga bahwa pada umur 28 HST unsur hara yang terkandung dalam pupuk kandang tersebut sudah mulai berkurang sehingga tidak dapat membuat perbedaan tinggi tanaman antar perlakuan dosis pupuk kandang.

\section{Jumlah daun (helai)}

Hasil penelitian menunjukkan tidak terdapat interaksi antara berbagai dosis pupuk kandang ayam dan dosis pupuk NPK terhadap parameter jumlah daun kubis bunga (Tabel 2). Hal ini diduga kombinasi dosis pupuk kandang ayam dan dosis NPK majemuk memberikan pengaruh sendiri-sendiri sehingga respons tanaman sama pada setiap peubah yang diamati. Hal ini juga terlihat pada penelitian Diana et al. (2020) yang menyatakan bahwa tidak terjadi interaksi antara perlakuan pupuk kandang dengan NPK pada tanaman kubis bunga.

Perlakuan dosis 20 ton pupuk kandang ha ${ }^{-1}$ pada umur 28 HST menunjukkan jumlah daun tertinggi. Begitu juga dengan perlakuan dosis $200 \mathrm{~kg}$ NPK ha $a^{-1}$ juga memberikan keragaman jumlah daun yang lebih banyak dibandingkan dosis yang lain. Hal ini disebabkan karena pada perlakuan tersebut memiliki kandungan unsur hara yang lebih baik daripada dosis yang lain. Dwidjoseputro (1985) menyatakan bahwa suatu tanaman akan tumbuh dengan subur bila semua unsur hara yang diperlukan tanaman berada dalam jumlah yang cukup serta berada dalam bentuk yang siap diabsorpsi oleh tanaman. Hasil penelitian ini sesuai dengan penelitian Shokalu et al. (2010) bahwa pupuk organik pada dosis 20 ton ha ${ }^{-1}$ dapat meningkatkan tinggi tanaman, jumlah daun, maupun ketebalan batang pada tanaman bunga boroco (Celosia argentea). Dengan pemberian pupuk kandang maupun pupuk NPK, maka pasokan unsur nitrogen lebih baik, sehingga tanaman mampu menghasilkan jumlah daun banyak (Novizan, 2002).

Tabel 2. Hasil analisis jumlah daun

\begin{tabular}{lcccc}
\hline \multirow{2}{*}{ Perlakuan } & \multicolumn{4}{c}{ Rata-rata jumlah daun (helai) } \\
\cline { 2 - 5 } & 7 HST & 14 HST & $21 \mathrm{HST}$ & $28 \mathrm{HST}$ \\
\hline Dosis pupuk kandang ayam & & & & \\
\hline 0 ton ha $^{-1}$ & $5,32 \mathrm{a}$ & $7,95 \mathrm{a}$ & $10,46 \mathrm{a}$ & $12,69 \mathrm{ab}$ \\
10 ton ha $^{-1}$ & $5,19 \mathrm{a}$ & $7,86 \mathrm{a}$ & $10,28 \mathrm{a}$ & $12,56 \mathrm{a}$ \\
20 ton ha $^{-1}$ & $5,18 \mathrm{a}$ & $7,90 \mathrm{a}$ & $10,79 \mathrm{a}$ & $13,16 \mathrm{~b}$ \\
\hline Dosis pupuk NPK & & & & \\
\hline $0 \mathrm{~kg} \mathrm{ha}^{-1}$ & $5,14 \mathrm{a}$ & $7,69 \mathrm{a}$ & $10,29 \mathrm{a}$ & $12,36 \mathrm{a}$ \\
$100 \mathrm{~kg} \mathrm{ha}^{-1}$ & $5,26 \mathrm{a}$ & $8,00 \mathrm{a}$ & $10,55 \mathrm{a}$ & $12,90 \mathrm{ab}$ \\
$200 \mathrm{~kg} \mathrm{ha}^{-1}$ & $5,29 \mathrm{a}$ & $8,02 \mathrm{a}$ & $10,69 \mathrm{a}$ & $13,16 \mathrm{~b}$ \\
\hline Interaksi & tn & tn & tn & tn \\
\hline
\end{tabular}

Keterangan : Angka rata-rata yang diikuti huruf yang sama pada setiap kolom, tidak berbeda nyata menurut Uji Jarak Berganda Duncan pada taraf 5\%, HST = hari setelah tanam, tn = tidak nyata

Hasil penelitian menunjukkan tidak terdapat interaksi antara berbagai dosis pupuk kandang ayam dan dosis pupuk NPK terhadap parameter luas daun kubis bunga (Tabel 3). Hal ini diduga kombinasi dosis pupuk kandang ayam dan dosis NPK majemuk memberikan pengaruh sendirisendiri sehingga respons tanaman sama pada setiap peubah yang diamati. Hal ini juga terlihat pada penelitian Diana et al. (2020) yang menyatakan bahwa tidak terjadi interaksi antara perlakuan pupuk kandang dengan NPK pada tanaman kubis bunga.
Berdasarkan Tabel 3, perlakuan 20 ton pupuk kandang ha ${ }^{-1}$ memiliki luas daun tertinggi dibandingkan perlakuan yang lain. Hal ini terjadi karena dosis 20 ton ha $^{-1}$ memiliki kandungan unsur hara yang lebih banyak terutama nitrogen dibandingkan dosis lainnya yang dapat memenuhi kebutuhan hara tanaman. Menurut Susilowati (2013) unsur hara makro pada pupuk kandang ayam terdiri dari $\mathrm{N}(1,72 \%), \mathrm{P}(1,82 \%), \mathrm{K}$ $(2,18 \%), \mathrm{Ca}(9,23 \%), \mathrm{Mg}(0,86 \%)$ dan beberapa unsur mikro seperti $\mathrm{Mn}, \mathrm{Fe}, \mathrm{Cu}, \mathrm{Zn}$ dan lain-lain. Menurut Husnihuda et al. (2017) bahwa unsur 
hara $\mathrm{N}, \mathrm{P}$ dan $\mathrm{K}$ memiliki peran penting dalam pertumbuhan tanaman. Jika kebutuhan hara tercukupi akan meningkatkan pertumbuhan tanaman. Hal ini diperkuat oleh penelitian Isdarmanto (2009) yang menyatakan bahwa pupuk kandang kambing, pupuk kandang ayam, pupuk sampah organik maupun pupuk organik sampah kota pada dosis 20 ton ha ${ }^{-1}$ dapat meningkatkan luas daun tanaman cabai. Hal ini juga sejalan dengan penelitian Amalia et al. (2019) bahwa pupuk kandang ayam dapat meningkatkan luas daun tanaman kubis bunga.

Tabel 3. Hasil analisis luas daun

\begin{tabular}{ll}
\hline \multicolumn{1}{c}{ Perlakuan } & Rata-rata luas daun $(\mathrm{cm})$ \\
\hline Dosis pupuk kandang ayam & \\
\hline 0 ton ha & \\
10 ton ha $^{-1}$ & $2754,26 \mathrm{a}$ \\
20 ton ha $^{-1}$ & $3819,66 \mathrm{ab}$ \\
\hline Dosis pupuk NPK & $4676,95 \mathrm{~b}$ \\
\hline $0 \mathrm{~kg} \mathrm{ha}^{-1}$ & \\
$100 \mathrm{~kg} \mathrm{ha}^{-1}$ & $3044,90 \mathrm{a}$ \\
$200 \mathrm{~kg} \mathrm{ha}^{-1}$ & $4096,79 \mathrm{a}$ \\
\hline
\end{tabular}

Interaksi tn

Keterangan : Angka rata-rata yang diikuti huruf yang sama pada setiap kolom, tidak berbeda nyata menurut Uji Jarak Berganda Duncan pada taraf $5 \%$, th $=$ tidak nyata

Berdasarkan Tabel 3 diketahui bahwa tanaman yang diaplikasikan pupuk kandang ayam menunjukkan lebih berpengaruh dibandingkan dengan perlakuan pupuk NPK. Hal tersebut disebabkan karena kandungan unsur $\mathrm{N}$ pada pupuk kandang ayam lebih tinggi serta lebih lengkap mengandung unsur hara makro dan mikro bila dibandingkan dengan pupuk NPK. Lingga dan Marsono (2005) menyatakan bahwa ketersediaan hara yang cukup dan seimbang mutlak untuk pertumbuhan dan perkembangan tanaman. Tingginya kandungan $\mathrm{N}$ tersebut meningkatkan luas daun kubis bunga.

\section{Hasil tanaman}

Hasil penelitian menunjukkan tidak terdapat interaksi antara berbagai dosis pupuk kandang ayam dan dosis pupuk NPK terhadap parameter berat krop (Tabel 4). Hal ini diduga kombinasi dosis pupuk kandang ayam dan dosis NPK majemuk memberikan pengaruh sendiri-sendiri sehingga respons tanaman sama pada setiap peubah yang diamati. Hal ini juga terlihat pada penelitian Diana et al. (2020) yang menyatakan bahwa tidak terjadi interaksi antara perlakuan pupuk kandang dengan NPK pada tanaman kubis bunga.

Perlakuan pupuk $200 \mathrm{~kg}$ NPK $\mathrm{ha}^{-1}$ menghasilkan nilai tertinggi terhadap parameter berat dan diameter krop. Dosis pupuk NPK yang cukup akan mempengaruhi ketersediaan unsur hara bagi tanaman sehingga optimal pertumbuhan dan perkembangannya (Lingga dan Marsono, 2005). Unsur hara yang cukup maka tanaman dapat melakukan proses fisiologis dengan baik. Hal ini sesuai juga dengan penelitian Prawoto dan Hartatik (2018) bahwa pupuk NPK dapat meningkatkan diameter krop kubis bunga.

Tabel 4. Hasil analisis berat krop

\begin{tabular}{lcc}
\hline \multicolumn{1}{c}{ Perlakuan } & Berat krop $(\mathrm{kg})$ & Diameter krop $(\mathrm{cm})$ \\
\hline Dosis pupuk kandang ayam & & \\
\hline 0 ton ha $\mathrm{ha}^{-1}$ & $0,34 \mathrm{a}$ & $21,00 \mathrm{a}$ \\
10 ton ha $^{-1}$ & $0,29 \mathrm{a}$ & $21,72 \mathrm{a}$ \\
20 ton ha $^{-1}$ & $0,35 \mathrm{a}$ & $22,11 \mathrm{a}$ \\
\hline Dosis pupuk NPK & & $18,67 \mathrm{a}$ \\
\hline $0 \mathrm{~kg} \mathrm{ha}^{-1}$ & $0,26 \mathrm{a}$ & $21,06 \mathrm{a}$ \\
$100 \mathrm{~kg} \mathrm{ha}^{-1}$ & $0,29 \mathrm{a}$ & $25,11 \mathrm{~b}$ \\
$200 \mathrm{~kg} \mathrm{ha}^{-1}$ & $0,44 \mathrm{~b}$ & $\mathrm{tn}$ \\
\hline Interaksi & tn & \\
\hline
\end{tabular}

Keterangan : Angka rata-rata yang diikuti huruf yang sama pada setiap kolom, tidak berbeda nyata menurut Uji Jarak Berganda Duncan pada taraf 5\%, krop = kubis bunga siap panen, tn = tidak nyata

\section{KESIMPULAN}

Tidak terdapat interaksi antara berbagai dosis pupuk kandang ayam dan pupuk NPK.
Perlakuan dosis 20 ton ha ${ }^{-1}$ pupuk kandang ayam mempengaruhi luas tinggi tanaman, jumlah daun dan luas daun kubis bunga. Perlakuan dosis $200 \mathrm{~kg} \mathrm{ha}^{-1}$ pupuk NPK mempengaruhi 
tinggi tanaman, jumlah daun, berat dan diameter krop kubis bunga. Perlu dilakukan penelitian lebih lanjut tentang pengaruh perlakuan pupuk kandang dan NPK dosis yang lain terhadap pertumbuhan dan hasil tanaman kubis bunga.

\section{UCAPAN TERIMA KASIH}

Penulis menyampaikan terima kasih kepada petani dan kepala Desa Desa Sukasenang, Kecamatan Banyuresmi, Kabupaten Garut atas pemberian izin penggunaan lahan penelitian, serta civitas akademika Program Studi Agroteknologi, Fakultas Pertanian, Universitas Garut atas bantuan dan kerjasamanya dalam menyelesaikan penelitian ini.

\section{DAFTAR PUSTAKA}

Amalia, S., Nurdiana, D., \& Maesyaroh, S. S. (2019). Pengaruh dosis pupuk kandang ayam dan cendawan Trichoderma sp. terhadap pertumbuhan dan hasil tanaman kubis bunga (Brassica oleracea var. Botritis L.). Jagros: Jurnal Agroteknologi dan Sains (Journal of Agrotechnology Science), 3(2), 122-135. http://dx.doi.org/10.52434/jagros.v3i2.865

Armidayani, Syammiah, \& Hayati, E. (2020). Pengaruh umur pindah bibit dan dosis pupuk NPK dengan penambahan pupuk hayati terhadap pertumbuhan dan hasil kubis bunga (Brassica oleraceae L.). Jurnal Agrista, 24(1), 40-58. Tersedia dari http://jurnal.unsyiah.ac. id/agrista/article/view/18845

Arpanto, R., \& Soenyoto, E. (2018). Pengaruh jenis mulsa dan dosis pupuk NPK mutiara terhadap pertumbuhan dan produksi tanaman kubis (Brassica olarecae) varietas PM $125 \mathrm{~F} 1$. Jurnal Ilmiah Hijau Cendekia, 3(1), 58-63. Tersedia dari https://ejournal.uniska-kediri.ac. id/index.php/HijauCendekia/article/view/107

Bahri. (2006). Pengaruh sumber pupuk terhadap pertumbuhan dan hasil tanaman kubis bunga. Prosiding Seminar Nasional Hortikultura, 307-310. Tersedia dari http://sumbar.litbang. pertanian.go.id/images/pdf/selada.pdf

BPS. (2015). Data produksi kol bunga. Badan Pusat Statistik. Tersedia dari https://www. bps.go.id/indicator/55/61/5/production-of-ve getables.html

Diana, S., Novriani, \& Citra, A. (2020). Respon pertumbuhan dan produksi kubis bunga (Brasscica oleracea L.) terhadap pemberian pupuk kandang dan NPK majemuk. Lansium, 1(2), 41-51. Tersedia dari http://journal. unbara.ac.id/index.php/Lansium/article/view/ 261

Dwidjoseputro, D. (1985). Pengantar fisiologi tumbuhan. Jakarta: Gramedia.

Husnihuda, M. I., Sarwitri, R., \& Susilowati, Y. E. (2017). Respon pertumbuhan dan hasil kubis bunga (Brassica oleracea Var. Botrytis, L.) pada pemberian PGPR akar bambu dan komposisi media tanam. Vigor: Jurnal Ilmu Pertanian Tropika Dan Subtropika, 2(1), 13-16. Tersedia dari https://jurnal.untidar. ac.id/index.php/vigor/article/view/321

Isdarmanto. (2009). Pengaruh macam pupuk organik dan konsentrasi pupuk daun terhadap pertumbuhan dan hasil tanaman cabai merah (Capsicum annum L.) dalam budidaya sistem pot. [Skripsi]. Fakultas Pertanian, Universitas Sebelas Maret, Surakarta.

Lingga, P., \& Marsono. (2005). Petunjuk penggunaan pupuk. Jakarta: Penebar Swadaya. Tersedia dari https://scholar.google. co.id/scholar?cluster $=6982555883263509565$ $\&$ hl=id\&as_sdt $=2005 \&$ sciodt $=0,5$

Mayadewi, N. N. A. (2007). Pengaruh jenis pupuk kandang dan jarak tanam terhadap pertumbuhan gulma dan hasil jagung manis. Jurnal Agritrop, 26(4), 153-159. Tersedia dari https://ojs.unud.ac.id/index.php/agritrop/ article/view/3069/2217

Murbandono, L. (2000). Membuat kompos. Jakarta: Penebar Swadaya. Tersedia dari https://scholar.google.co.id/scholar?cluster $=1$ 4139153184566549821\&hl=id\&as_sdt=2005 \&sciodt $=0,5$

Novizan. (2002). Petunjuk pemupukan yang efektif. Jakarta: Agro Media Pustaka.

Prawoto, T. Y., \& Hartatik, S. (2018). Respon pertumbuhan dan hasil beberapa varietas bunga kol (Brassica oleracea Var. Botrytis L.) terhadap penggunaan pupuk majemuk NPK di dataran rendah. Seminar Nasional Program Studi Agribisnis Fakultas Pertanian Universitas Jember, 718-731. Tersedia dari https://jurnal.unej.ac.id/index.php/prosiding/a rticle/view/8976 
Putri, A. D., Wagiono, Subardja, V. O., \& Hakim, L. (2021). Pengaruh kombinasi dosis pupuk vermikompos dan pupuk NPK terhadap pertumbuhan dan hasil tanaman kubis bunga (Brassica oleracea var botrytis L.). Jurnal Agrotek Indonesia, 6(1), 8-14. Tersedia dari https://journal.unsika.ac.id/index.php/agrotek/ article/view/4794

Rinsema, W. T. (1989). Pupuk dan cara pemupukan. Jakarta: Bhatara Karya Aksara.

Rukmana, R. (1994). Budidaya kubis bunga dan brokoli. Yogyakarta: Kanisus.

Saepuloh, Isnaeni, S., \& Firmansyah, E. (2020). Pengaruh kombinasi dosis pupuk kandang ayam dan pupuk kandang kambing terhadap pertumbuhan dan hasil pagoda (Brassicaee narinosa L.). Agroscript, 2(1), 34-48. https://doi.org/10.36423/agroscript.v2 i1.500

Shaila, G., Tauhid, A., \& Tustiyani, I. (2019). Pengaruh dosis urea dan pupuk organik cair asam humat terhadap pertumbuhan dan hasil tanaman jagung manis. Jurnal Agritop, 17(1), 35-44. https://doi.org/ 10.32528/agritrop.v17i1.2185

Shokalu, A. O., Ojo, A. O., Ezekiel-Adewoyin, D. T., Akinwunmi, A. H., \& Azeez, J. O. (2010).
Comparing the use of Tithonia diversifolia and compost as soil amendments for growth and yield of Celosia argente. New York Science Journal, 3(6), 133-138. Tersedia dari http://www.sciencepub.net/newyork/ny0306/2 0_2680_ny0306_133_138.pdf

Sugiyanta, Tustiyani, I., Melati, M., \& Nurrizki, A. (2021). Soil fertility and yield of rice during two season on organic and inorganic fertilized. Proceedings of the 1st International Conference on Islam, Science and Technology, ICONISTECH 2019, 1-10. https://doi.org/ 10.4108/eai.11-7-2019.2303557

Susilowati, A. (2013). Pengaruh pemberian pupuk kotoran ayam dan pupuk kotoran kambing terhadap produktivitas tanaman cabai merah keriting (Capsicum annum L.). [Skripsi]. Universitas Muhammadiyah Surakarta. Tersedia dari http://eprints.ums. ac.id/26725/

Tustiyani, I., Sugiyanta, \& Melati, M. (2014). Karakter morfofisiologi dan fisikokimia beras dengan berbagai dosis pemupukan organik dan hayati pada budidaya padi organik. Jurnal Agronomi Indonesia, 42 (3), 187-194. Tersedia dari https://journal. ipb.ac.id/index.php/jurnalagronomi/article/vie w/9162 